\title{
The impacts of financial development on growth: A time-varying causality analysis for Turkey*
}

\author{
Mehmet Zeki Ak ${ }^{1}$, Mustafa Kirca ${ }^{2}$, Nurullah Altintaş ${ }^{3}$
}

\begin{abstract}
The goal of this research is to determine whether the causal relationship between financial development and economic growth in Turkey is stable over time. For this purpose, causal relationship between financial development and economic growth in Turkey has been investigated by means of annual data for the period of 19602013. Differently from previous studies in the literature, considering that causal relationship between financial development and economic growth might change depending on time, time-varying causality test developed by Balcilar, Ozdemir and Arslanturk (2010) has been used. The results show that there is a unidirectional causal relationship from financial development to economic growth and this relationship changes depending on time. It is seen that unidirectional causality from financial development to economic growth emerged during the periods of financial turmoil and political crisis. The basic conclusion is that there is no stable causal relationship between financial development and economic growth in Turkey over the given time period.
\end{abstract}

Key words: financial development, growth, time-varying causality

JEL classification: C2, G10, G20, O43

\footnotetext{
* Received: 21-01-2016; accepted: 09-12-2016

1 Assistant Professor, Department of Economics, Faculty of Political Sciences, Sakarya University, 54187 Serdivan, Sakarya, Turkey. Scientific affiliation: financial development, economic growth. Phone: +90 264295 6195. E-mail: mak@sakarya.edu.tr.

2 Research Assistant, Institute of Social Sciences, Anadolu University, 26470 Eskişehir, Turkey. Scientific affiliation: macroeconomics, tourism economics, time series analysis. Phone: +90 2223350580 1269.E-mail: mustafakirca@anadolu.edu.tr.

3 Research Assistant, Department of Economics, Faculty of Political Sciences, Sakarya University, 54187 Serdivan, Sakarya, Turkey. Scientific affiliation: financial development, economic growth, econometrics. Phone: +90264295 6195. E-mail: naltintas@sakarya.edu.tr (corresponding author).
} 


\section{Introduction}

The economic policies applied in Turkey show dramatic changes as a result of domestic and international dynamics. Development policies based on import substitution started to dominate the economic policy in 1963. Shocking socialeconomic and political crises which emerged in 1970's led to a set of significant transformations in Turkey like the other various countries. In the beginning of 1980 a new development policy based on international expansion led by export was adopted by the famous program known as 24 January Decisions. The prominent character of transformation carried out by 24 January Decisions is that it adopts significant amendments for making the financial system deeper and more comprehensive. The transformation of the financial system should be categorized into three sub-periods: The first period, which lasted from 1980 to 1989 can be regarded as domestic financial liberalization. In this period the government kept making legislative and institutional regulations however the interest rates were liberated, the merging of banks was made simpler and a capital market was created. And some institutional structures such as Saving Deposit Insurance Fund, Interbank Money Market, İstanbul Stock Exchange Market were founded and The Central Bank started to carry out open market operations. The second period, which lasted from 1989 to 2001 can be regarded as international financial liberalization however a period of crises as well. In 1989 international capital movements and the foreign exchange regime were liberated. Short-run hot money stared to flow into Turkish financial markets. Banking Regulation and Supervision Agency (BDDK) was founded in 1999 (as an extension of structural reforms initiated in 1980). However Turkish economy went through a number of sharp fluctuations of growth and real interest rates, chronic high inflation levels, public deficit and balance of payments problems made macroeconomic instability rise. As might be expected, this led to an increase in the risk of the banking sector and that of the country. Besides, the banks moved away from their conventional functions of converting deposits into credits, they tended to finance public deficits. This risky structure of Turkish economy made the banking sector considerably fragile for domestic and international shocks. The conflicting economy was exposed to 1994 crisis and then 2001 crisis. The third period, which lasted from 2001 up to now, can be regarded as institutional reform and stability period. Restructuring of the banking sector was the prominent character of the Transition to the Strong Economy Program, which was carried out right away after the crisis. The transition of the banking sector had three steps. At the first step, the banks which were unable to pay their debts were nationalized and the government banks were restructured and their capitals were enhanced. At the second step, the weak banks which were unable to strengthen their capital structures were encouraged to exit the system. At the third step, some significant regulations were carried out in order to fulfill the lack of management effectiveness and optimal supervision. 
The study which examines the period of 1960-2013 of Turkish economy is expected to contribute to financial development and economic growth literature on four points. (1) The main dissimilarity that differs this article from previous studies in which Granger causality tests were used is the use of time-varying causality test developed by Balcilar, Ozdemir and Arslanturk (2010) who have taken "causality's feature of being non-stationary" into consideration. (2) Turkey is one of five countries most affected by monetary policy change announced by U.S Federal Reserve in May 2013. With effect of domestic political uncertainty of recent years, Turkey has come to a more risky position among "fragile five" countries comparing to others due to current deficit and external financial dependency. In the face of instability in finance markets, analyzing those sides of economy that could cause fragility and implementing policies to overcome these fragilities are significant to ensure sustainable economic growth. (3) By testing the assumption that financial liberalization would directly and mechanically lead to the growth in specific context of Turkey's economy, additional findings will be contributed to literature which has taken shape within the context of direction of the relationship between "financial development" and "growth". (4) In order to obtain solid results presenting effect of financial development on growth in Turkey, a sufficiently large set of data belonging to the period of 1960-2013 has been used in the study.

The basic hypothesis of the study is that 'there is a causal relationship between financial development and economic growth in Turkey but this relationship isn't stable over time'.

The paper is organized as follows: section 2 provides a literature review, section 3 explains the time varying bootstrap analysis, section 4 , describes the data and provides the empirical results, section 5, subsequently, discusses the results, section 6 , provides conclusions.

\section{Literature review}

First evaluations regarding the relationship between financial development and "growth" were carried out by Schumpeter (1911) a century ago. Does such relationship exist? If there is, how is the direction of that relationship? Although many years have passed, ever-lengthening heated debates over these questions and empirical studies triggered by these debates still keep up-to-date. In other words, there is an extremely large literature containing discussions that have been made to determine "direction" and "degree" of relationship between "financial development" and "growth". The literature in which relationship between financial development and growth has been discussed comprises scores of studies concerning to the developed and developing countries. By performing analysis on various econometric methods, variables and periods, causal relationship between "financial development" and "growth" has been examined in these studies. 
The literature on theoretical bases of financial sector's role in process of economic development, which was one of the most interested subjects in 1950s and 1960s, improved over the period from mid-1950s until early 1980s. In addition, that financial liberalization policies became indivisible part of stability programs supported by international organizations such as IMF and World Bank and applied in many countries paved the way for a swift increase in empirical studies. When the development process of finance-growth literature from 1950s until today is examined, it's seen that empirical studies have basically adopted three econometric methodologies. In the first group, cross-sectional modeling approach based on examination of different variables at one time point has been adopted and finance-growth relationship in more than a country has been examined. Within this framework, results supporting the hypothesis of "supplyleading", which was stated in studies by King and Levine (1993), Fry (1995), Levine (1998), Levine and Zervos (1998), that means financial development leads to growth have been reached. Studies on cross-section reveal extensive evidence that financial development plays an active role in growth process and accelerates growth.

The second group has adopted time series modeling approach in order to show finance-growth relationship in a more clear way. Although cross-sectional analysis has made significant contributions to the literature to understand financegrowth relationship, it's been subjected to various criticisms that its results are not reliable. Arestis and Demetriades (1997) who defended time series modeling criticized cross-sectional approach, arguing it did not take country-specific factors into account and was based on assumption that countries had similar economic structures. They also put forward that existence of different causality structures in different countries restricted cross-sectional causality analysis and this restriction could only be overcome by time series approach. Levine and Zervos (1998) and Demetriades and Hussein (1996) agreed on the idea and thought that question of causality could not be successfully answered by cross-section structure.

In empirical studies carried out by using time series modeling, different results were obtained regarding to causality link between finance and growth. While Gupta (1984), Jung (1986), Neusser and Kugler (1998), Demetrias and Hussein (1996), Choe and Moosa (1999), Rousseau and Watchell (2000), Shan et al. (2001) have stressed positive effect of financial development on growth in their studies, Shan and Morris (2002), Ang and McKibbin (2007), Odhiambo (2008), Yang and Yi (2008) have argued that economic growth leads to financial development. Arestis and Demetriades (1997), Demetriades and Luintel (1996), Luintel and Khan (1999), and Arestis et al. (2001) presented evidence for existence of bidirectional causality. Results of time series studies indicate by and large that direction of causality relationship between finance and growth could change depending on development levels of countries and policies they apply. 
The third group has adopted approach of panel data modeling and examined finance-growth relationship in more than one country. Although some strong evidences have been presented regarding to country-specific time series and finance-growth relationship, disputable results have been obtained due to shortness of data set and possibility of getting deviant outcomes when standard tests are applied. Since it allows causality relationship to be tested in more efficient way with more observation, use of panel data has recently become widespread in empirical literature. According to Hsiao (2003), observation number increases considerably because both cross-section and time series data are used in panel data models. That the number of observation is higher comparing to traditional methods increases degrees of freedom and reduces the possibility of high degrees of linear relationship among explanatory variables.

According to findings of Calderon and Liu (2003) Al-Yousif (2002), Acaravci et al. (2009), Bangake and Eggoh (2011), Pradhan et al. (2013), and Hassan et al. (2011) that examined the relationship between financial development and economic growth within the framework of panel data, it has been ascertained that there is bidirectional causality between these two variables. While Beck et al. (2000), Levine et al. (2000), Christopoulos and Tsionas (2004), Dawson (2008), Hsueh et al. (2013), Nazlioglu et al. (2014) assert that financial development leads to economic growth, Kar et al. (2011) claim financial development's role in growth process is ambiguous.

In empirical studies carried out about Turkey, direction of causality relationship between financial development and economic growth has been mainly focused on. Literature on causality relationship between financial development and economic growth has been summarized essentially in four categories in the study. The first category consists of studies which support the view that financial development is determinant for economic growth (supply-leading). Cetinbas and Barisik (2003) analyzed the existence of relationship among development of banking system, development of capital market and economic growth with monthly data for the period of 1989-2000 through Johansen co-integration and Granger causality tests. The findings indicate a unidirectional causality from developments in capital market and banking sector to economic growth. Similarly in a study in which quarterly data for Turkey's 1986:1-2006:4 period were used, Acaravci et al. (2007) concluded, just like the previous study's findings, that financial development stimulated the growth.

The second category comprises studies which support the view that financial development is the result of economic growth (demand-following hypothesis). A strong causality relationship from growth to financial development has been revealed in the studies of Nazlioglu et al. (2009) where six different financial development variables were used. In another study, Ozturk (2008) investigated causality relationship between annual real Gross Domestic Product (GDP) and loan volume provided for private sector by banking sector for the period of 1975-2005 in 
Turkey and found out the existence of a unidirectional relationship from economic growth to financial development.

The third category consists of the studies which identify the presence of interrelation in contrary to unilateral causality relationship which the previous studies have reached between financial development and economic growth. According to the outputs of Granger causality test applied by Unalmis (2002) by using annual data of 1970-2001 period, there is a causality relationship from financial development to economic growth (except for a variable) in the short term. Long term causality relationship between growth and financial development is bidirectional. In another study, he analyses causality relationship between financial development and growth on the basis of vector error correction and impulseresponse function by using annual data dating back to Demirhan et al. (2011), 1987:1-2006:4. "Gross domestic product" has been used as an indication of the growth and "bank credits transmitted to private sector" and "market capitalization rate" have been used as an indication of financial development in the established model. The findings reveal that there is bilateral causality relationship between growth and financial development. Similarly, Arac and Ozcan (2014) have studied the relationship between financial development and growth with quarterly data of 1987-2012. Bilateral relationship between all indicators of financial development and economic growth was determined in the study where eight different financial development indicators have been used. According to the study, direction of long and short term causality relationship between financial development and growth depends on the indicator used.

The fourth category is the studies revealing no causality relationship between financial development and economic development. Soytas and Kucukkaya (2011) have analyzed the relationship between financial development and economic growth with quarterly data of 1991-2005 in Turkey through Toda and Yamamoto (1995) approach. Checking the potential effects of inflation, monetary and fiscal policy on monetary magnitude and economic growth, they have reached the results revealing no long term causality relationship between financial development and growth.

\section{Methodology}

The analysis has been conducted in order to measure how financial development and commercial liberation effect the growth includes four-stage test. Characteristics of time set of variables have been identified at the first stage. The Augmented DickeyFuller (ADF), Phillips-Perron (PP) and Kwiatkowski, Phillips, Schmidt, and Shin (KPSS) and Zivot and Andrews (ZA) one-break unit root tests have been applied to sets within the extent of stability analysis. At the second stage, the presence of co-integration between the variables has been laid down upon conduction of 
Johansen (1988) test. As known, co-integration analysis provides a framework which helps prediction and testing of long-term (balance) relationship between variables. At the third stage, with respect to unit root analysis results, Granger's causality approach and Toda and Yamamoto's (1995) approach will be used in attempt to identify the course of relationship between economic growth and financial development. Finally, a study will be conducted on which sub period causality relationship between Time-Varying Causality Analysis developed by Balcilar, Ozdemir and Arslanturk (2010) and variables shall be valid. In our analyses, Eviews 9 package has been employed. Besides, while analyzing the causality changing over time, the required codes which were obtained by Balcilar, Ozdemir and Arslanturk (2010) have been run in Eviews9 package.

The presence or absence of a causality relationship for the whole sample period has been studied in conventional causality tests of Granger. Moreover, standard causality analyses assume that there is a stable relationship between two variables. On the other hand, Granger's causality relationship between the sets depending on time can change in time under the effect of global or national economic and political issues. This means; this stability of causality relationship can be tested by using time-varying causality analysis. Our vector auto regression (VAR) model which is used in this study and time-varying causality analysis developed by Balcilar, Ozdemir and Arslanturk (2010) is as follows:

$$
\begin{aligned}
& {\left[\begin{array}{l}
\Delta \ln C G D P_{t} \\
\Delta \ln P S C_{t}
\end{array}\right]=\alpha_{0}+\alpha_{1}\left[\begin{array}{l}
\Delta \ln C G D P_{t-1} \\
\Delta \ln P S C_{t-1}
\end{array}\right]+\ldots} \\
& \ldots+\alpha_{P}\left[\begin{array}{l}
\Delta \ln C G D P_{t-p} \\
\Delta \ln P S C_{t-p}
\end{array}\right]+u_{t}
\end{aligned}
$$

As can be seen in equity (1), $\alpha_{0}$ stands for constant vector, $\alpha_{\mathrm{p}}$ stands for vector connected to parameters, " $p$ " is number of lag and $u_{t}$ stands for error term. LNCGDP is the logarithm of real gross domestic product, LNPSC is the logarithm of private sector credit to the GDP .It is essential to determine the value of "p" during VAR model analysis. Information criteria such as Akaike Information Criteria (AIC) are being used in order to identify this.

Johansen (1988 and 1991) and Johansen and Juselius (1990) have conducted cointegration analysis bu using VAR model. The reason for their practice: Engle and Granger (1987) have stated that even if two series are not stable itself, the linear combination of these can be stable. They have pointed out that these variables can be co-integrated in this occasion. For this purpose, if degree of our variables is stable (1), Johansen Co-integration Analysis should be used. Granger's Causality Analysis can be conducted by means of vector error correction model (VECM) during the following stage. If there is no long-term relationship between variables, Granger's Causality Analysis is conducted by the help of VAR model. In this case, our VAR Model will be as follows: 


$$
\begin{aligned}
& \Delta \ln C G D P_{t}=\alpha_{1}+\sum_{p=1}^{k} \beta_{1 p} \Delta \ln P S C_{t-p}+\sum_{p=1}^{k} \delta_{1 p} \Delta C G D P_{t-p}+\varepsilon_{1 t} \\
& \Delta \ln P S C_{t}=\alpha_{1}+\sum_{p=1}^{k} \beta_{2 p} \Delta \ln P S C_{t-p}+\sum_{p=1}^{k} \delta_{2 p} \Delta C G D P_{t-p}+\varepsilon_{2 t}
\end{aligned}
$$

Granger Causality Test will be conducted with the equity numbered (2) and (3) with the help of VAR model at the third stage of the study. Toda-Yamamoto (1995) Causality Test will be practiced at the following stage. Apart from Granger's causality test, Lag is incorporated into VAR model with an extent of maximum integration degree of sets. In this case, VAR ( $\mathrm{p}+\mathrm{dmax})$ model will have been established. The foremost advantage of Toda-Yamamoto (1995) test is that having different stable levels of varieties which have been incorporated into the analysis doesn't pose a problem and there is no necessity to calculate the difference of the variables which are not stable in its degree.

There are 4 hypotheses in aforementioned causality tests. These hypotheses suggest no causality from LNPSC to LNCGDP and from LNCGDP to LNPSC and bidirectional causality or any causality between the two. These results are produced with the help of Wald F test statistics. Whether there is causality from LNPCS to LNCGDP is tested with $\mathrm{F}$ statistics test which is applied to $\beta$ coefficients. Whether there is causality from LNCGDP to LNPSC is tested with F statistics test which is applied to $\delta$ coefficients.

Causality analysis is conducted for the whole sampling period in Granger and TodaYamamoto causality analysis. For this reason, Time-Varying Causality Analysis will be performed at the last stage of the study. This analysis has been developed by Balcilar, Ozdemir and Arslanturk (2010). As Arslantürk, Balcilar and Ozdemir (2011) have pointed out there is a causality relationship during some period within the evaluated period while there may not be a causality relationship in other period because causality relationship between two variables may not be stable during the evaluated period. Structural alterations existing within the evaluated period may effect causality periods. Balcilar, Ozdemir and Arslanturk (2010) have conducted rolling window Granger causality analysis so as to observe the effects of structural alterations on causality periods. VAR (p) process to be used in this analysis has been described as follows in Balcilar, Ozdemir and Arslanturk's (2010) study:

$$
y_{t}=\Phi_{0}+\Phi_{1} y_{t-1}+\ldots \Phi_{p} y_{t-p}+\varepsilon_{b} t=1,2, \ldots, T
$$

where $\varepsilon_{t}$ is a white noise process with a nonsingular covariance matrix and a zero mean. Available number of lag defined for this test (p) is the same as the lag length which is measured for number (1) VAR equality. For a bivariate equality, VAR process can be simplified as follows: 


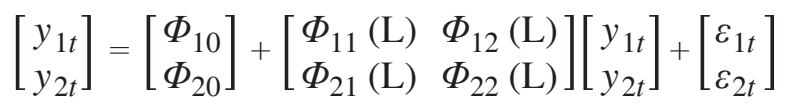

$\mathrm{y}_{1 t}$ term in the equality (5) stands for LNPSC variable for this study and, $\mathrm{y}_{2 t}$ stands for LNCGDP. $\varphi_{i j}(L)$ term included herein can be defined as follows;

$$
\sum_{k=1}^{p} \Phi_{i j, k} L^{k}, \quad i, j=1,2
$$

Term "L" is lag processor.

A test is applied so as to determine if $\varphi_{12, i}$ coefficient is equivalent to 0 for identifying whether LNCGDP leads to LNPSC. On the other hand, reverse causality hypothesis is determined by testing whether $\varphi_{21, i}$ is equivalent to 0 .

Besides Granger's causality analysis conducted for the whole sample, $t=\tau-l+1$, $\tau-l, \ldots, \tau, \tau=l, l+1, \ldots, T$ they have performed bootstrap causality tests for subperiods. ${ }^{4} 15$ rolling windows have been used in this study. 1 stands for the number of rolling windows herein.

The relationship to be taken into consideration in Time-Varying causality analysis is causality aspect that is indicated by Granger and Toda Yamamoto (1995) studies.

Within this method, modified LR statistic for each Rolling window is calculated for each sub-period. This statistic has chi-square division and can be calculated as follows:

$$
L R=(T-k) \ln \left(\frac{\operatorname{det} S_{R}}{\operatorname{det} S_{U}}\right)
$$

In the formula of LR statistic, $T$ stands for total number of observations, $k=2 \times(2 p+1)+p(p=$ available number of lag $)$, det $\mathrm{S}_{\mathrm{R}}$ stands for covariance matrix of unrestricted model; $\operatorname{det}_{\mathrm{U}}$ stands for covariance matrix of restricted model. Then, probability values are calculated for this statistic.

The values of this statistic under 0,20 are considered as a period when significant causality relations of Arslantürk, Balcilar and Ozdemir'in (2011) exist. In this study, the periods covering LR values under 0,20 will be regarded as a period of causality relations.

\footnotetext{
$\overline{4}$ A further information regarding this method can be seen in the studies of Balcilar, Ozdemir and Arslanturk (2010), Arslantürk, Balcilar and Ozdemir (2011), Nyakabawo, Miller, Balcilar, Das and Gupta (2015).
} 
Following this stage, bootstrap estimators make calculation for each aforementioned rolling window by using the same method followed by Balcilar, Ozdemir and Arslanturk $(2010)^{5}$. Thanks to these estimators it can be observed that whether a causality from a variable to another is negative or positive. Lower and upper limits are calculated by using $95 \%$ confidence intervals. Thus, reliability of analyses is tested.

\section{Empirical data and analysis}

\subsection{Data}

Data used in this paper is the annual data from 1960 to 2013 of domestic credit to private sector credit as a share of gross domestic product (PSC) and real gross domestic product (RGDP). The data have been obtained from the World Bank's database. No seasonality effect has been found in each set. The data is obtained from the World Bank's database.

In this study, private sector credit to GDP ratio has been included as a variable measuring the efficiency of banking sector in turning the savings into a state (credit) where private sector makes use of it. This parameter (PSC), is not only a criteria measuring development of banking sector but also shows the opportunities of new establishments in benefiting fiscal system through the bank (Baltagi et al., 2009). According to Levine et al. (2000) financial systems that transfer more credit for private sector than public sector activate more savings. Herwartz and Walle (2014) suggest that this parameter (PSC) is more effective in measuring financial intermediation activity with regards to its exclusion of credits granted to public sector by the central bank. Ang and Mckibbin (2007) emphasize that giving preference to the said parameter is favorable, considering private sector's effective and active use of funds as against public sector.

In 1990's Turkish banking sector focused on financing budget deficits rather than stimulating economic growth by transmitting the savings to the investment. In this regard Ismihan et al. (2013) and Ismihan and Ozkan (2012) suggest that it gives coherent financial development measurements to use demonstrators based on banking. Kar et al. (2008) suggest the index consisting of both monetary and credit extent and capital market indicators in order to measure financial development level. Expanding the index in a manner that includes banking and capital market variables will extend the information relating to financial development. In other words, inclusion of different indicators connected to banks and capital markets in indexes becomes more of an issue in terms of analysis because it reflects different functions of financial markets.

\footnotetext{
5 A further information regarding coefficient calculations can be found the studies of Balcilar, Ozdemir and Arslanturk (2010, p. 1403)
} 
Figure 1: Graphs of variables (1960-2013)

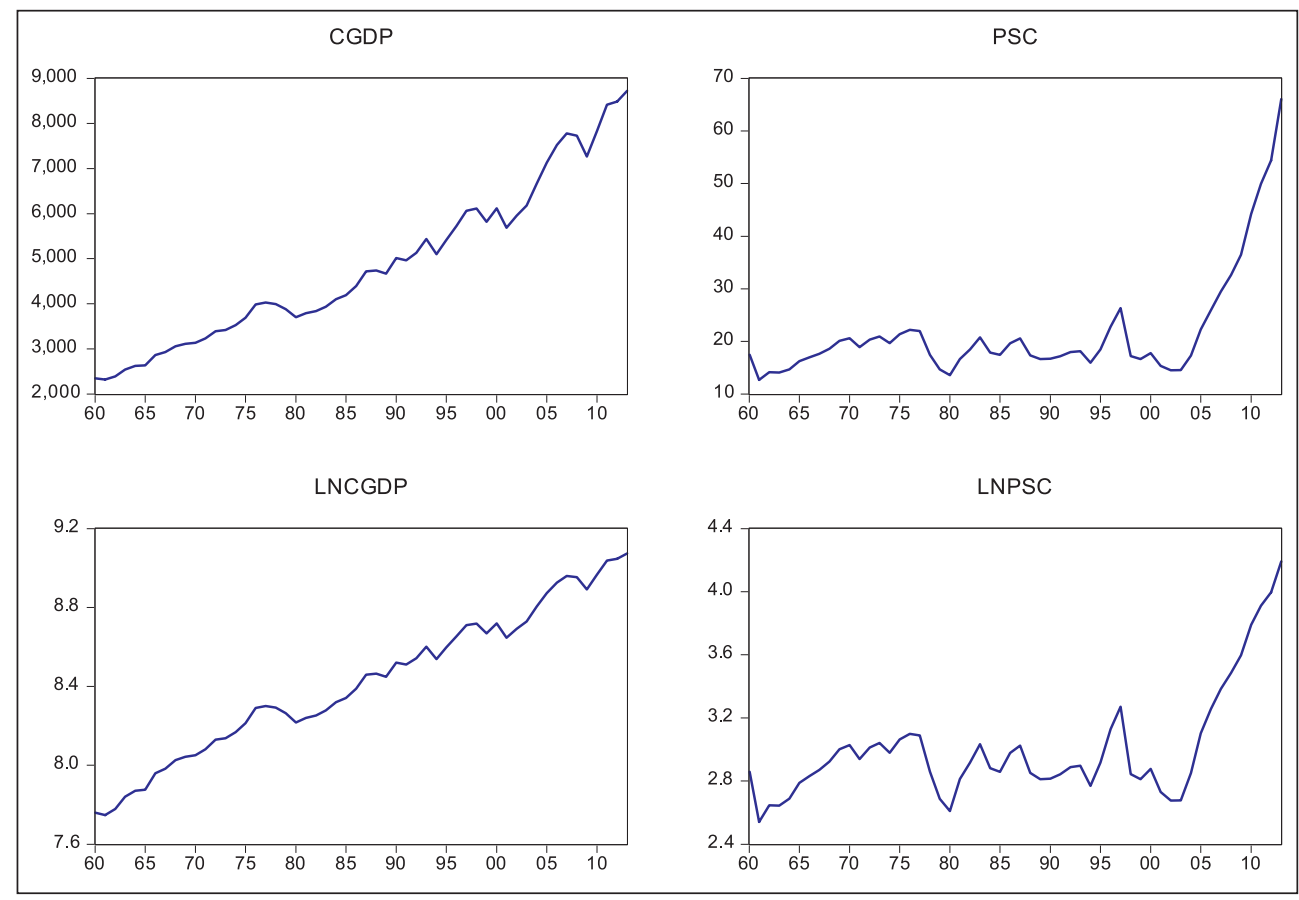

Source: Authors' calculations

Before econometric analyses, the course of the data in 1960-2013 is given in Figure 1. The log of these data series has been taken into account in the empirical analyses of this study. Economic crises and the structural breaks led by economic policy changes can be tracked in the graph.

\subsection{Empirical analysis}

In the course of evaluation of time-varying causality relations between financial development and growth, The Augmented Dickey-Fuller (ADF), Phillips-Perron (PP) and Kwiatkowski, Phillips, Schmidt, And Shin (KPSS), unit root tests have been applied at the first stage so as to identify stability of the sets. The results of unit root tests are given in Table 1. According to the results of unit root tests applied on level values of the variables, null hypothesis is accepted where the set is not stable or the sets have unit root. The sets become stable only after calculation of sets' first difference. Null hypothesis is rejected because test statistic calculated for the first difference for ADF and PP test is higher than the critical value in terms of absolute value and KPSS test statistics are lower than critical values in its first difference. Each of unit root tests (ADF, PP and KPSS) that are used for observing stability of the sets is supportive of each other. 
Table 1: Unit root test results

\begin{tabular}{|l|r|r|r|r|r|r|}
\hline \multirow{2}{*}{ Variables } & \multicolumn{2}{|c|}{ ADF } & \multicolumn{2}{c|}{ PP } & \multicolumn{2}{c|}{ KPSS } \\
\cline { 2 - 7 } & Intercept & $\begin{array}{c}\text { Intercept } \\
\text { and Trend }\end{array}$ & Intercept & $\begin{array}{c}\text { Intercept } \\
\text { and Trend }\end{array}$ & Intercept & $\begin{array}{c}\text { Intercept } \\
\text { and Trend }\end{array}$ \\
\hline LNCGDP & -0.396078 & -2.99958 & -0.368297 & -2.99958 & 1.003121 & 0.0806 \\
\hline LNPSC & 0.817459 & -0.283814 & 0.710027 & -0.550973 & 0.470664 & 0.14786 \\
\hline DLNCGDP* & $-7.456583^{*}$ & $-7.387608^{*}$ & $-7.474327^{*}$ & $-7.403439^{*}$ & $0.044506^{*}$ & - \\
\hline DLNPSC & $-6.089102^{*}$ & $-6.185908^{*}$ & $-6.089014^{*}$ & $-6.186364^{*}$ & $0.358041^{*}$ & $0.11243^{*}$ \\
\hline $\begin{array}{l}5 \%, 1 \% \\
\text { critical values } \\
\text { equals }\end{array}$ & -2.918778 & -3.498692 & -2.918778 & -3.498692 & 0.463 & 0.146 \\
\hline
\end{tabular}

Note: * shows the stability at 5\% significance level. LNCGDP is the logarithm of real gross domestic product, LNPSC is the logarithm of private sector credit to the GDP, DLNCGDP is the natural logarithm of Real gross domestic product, DLNPSC is the natural logarithm of private sector credit to the GDP.

Source: Authors' calculations

Standard unit root tests may give deviant results in case of occurrence of structural brakes in time sets. A unit root test has been conducted which was developed by Zivot and Andrews (1992) (ZA) in order to make up this deficiency and by this a structural break is identified internally. ZA unit root tests are shown in Table 2. According to the results given in Table 2, null hypothesis could not be rejected for any time set. As null hypothesis cannot be rejected, the sets are not stable in time. Within this context, ZA test results are coherent with conventional unit root tests which ignore structural breaks.

Break dates identified generally can be associated to financial developments before and/or within the said period. It is highly-likely that structural break estimated for Reel GDP set stemmed from 1979 crisis. Turkish economy was exposed to convulsive socio-economic and political crisis of 70's and lost the stability.

Turkey adopted import based growth conception after abandoning national developmentalist policy which was built on import-substitution approach basis so as to resolve the big 1979 crisis. Besides this, the first significant break in private sector credits falls on November 2000 and February 2001 crisis when Turkish banking sector entered into collapse period due to the loss as a result of the currency and interest risk. The year 2005 when institutional reforms executed after 2001 Crisis ensured recovery of Turkish economy falls on date of the second estimated structural break for private sector credit sets. 
Mehmet Zeki Ak, Mustafa Kirca, Nurullah Altintaş • The impacts of financial development...

Table 2: Structural break unit root test result

\begin{tabular}{|l|r|c|c|c|}
\hline \multirow{2}{*}{\multicolumn{1}{|c|}{ Variables }} & \multicolumn{4}{|c|}{ Zivot-Andrews } \\
\cline { 2 - 6 } & Intercept & Break & $\begin{array}{c}\text { Intercept and } \\
\text { Trend }\end{array}$ & Break \\
\hline LNCGDP & -4.025414 & 1979 & -4.644633 & 1979 \\
\hline LNPSC & -1.926424 & 2005 & -4.411456 & 2001 \\
\hline DLNCGDP* & $-7.728665^{*}$ & - & $-7.69929^{*}$ & - \\
\hline DLNPSC $^{*}$ & $-6.839720^{*}$ & - & $-6.727795^{*}$ & - \\
\hline Critical Values for Significance at 5\% $^{*}$ & -4.93 & - & -5.08 & - \\
\hline
\end{tabular}

Note: $*$ shows the stability at $5 \%$ significance level. LNCGDP is the logarithm of real gross domestic product, LNPSC is the logarithm of private sector credit to the GDP, DLNCGDP is the natural logarithm of real gross domestic product, DLNPSC is the natural logarithm of private sector credit to the GDP.

Source: Authors' calculations

Upon observing that the sets are first degree stable, Johansen cointegration analysis has been applied at the second stage. As known, this analysis is susceptible to the selection of lag length. For this reason, VAR model has been created for identifying number of lag to be used in co-integrity test. Lag length has been determined as two with the help of information criteria. When diagnostic test controls are reapplied based on VAR model, no autocorrelation and varying variant concern have been observed in two lagged model.

Table 3: Johansen cointegration test results

\begin{tabular}{|c|c|c|c|c|c|}
\hline $\mathrm{H}_{0}$ & $\mathrm{H}_{1}$ & Core Values & Trace Statistic & $\begin{array}{c}5 \% \text { Critical } \\
\text { Values }\end{array}$ & Prob $^{* *}$ \\
\hline $\mathrm{r}=0$ & $\mathrm{r} \geq 1$ & 0.082428 & 4.921519 & 15.49471 & 0.8171 \\
\hline $\mathrm{r} \leq 1$ & $\mathrm{r} \geq 2$ & 0.008583 & 0.448246 & 3.841466 & 0.5032 \\
\hline & \multicolumn{5}{|c|}{ Test Results of Max. Core Values Test Statistic } \\
\hline $\mathrm{H}_{0}$ & $\mathrm{H}_{1}$ & Core Values & $\begin{array}{c}\text { Maximum Core } \\
\text { Value Statistic }\end{array}$ & $\begin{array}{c}5 \% \text { Critical } \\
\text { Values }\end{array}$ & Prob $^{* *}$ \\
\hline $\mathrm{r}=0$ & $\mathrm{r}=1$ & 0.082428 & 4.473273 & 14.2646 & 0.8063 \\
\hline $\mathrm{r} \leq 1$ & $\mathrm{r}=2$ & 0.008583 & 0.448246 & 3.841466 & 0.5032 \\
\hline
\end{tabular}

Note: * shows long-term relations for significance level at $5 \%$.

Source: Authors' calculations

Johansen cointegration test Intercept (no trend) in Cointegration equation and test VAR. It can be identified whether there is a long-term balance relationship among the variables with the help of maximum eigenvalue and trace statistics. As can be seen in Table 3, Maximal eigenvalue test statistic is under critical value of 5\%. Thus, 
principle hypothesis claiming no co-integration relationship among the variables $(\mathrm{r}=0)$ cannot be rejected. As trace test statistic is under critical value of $5 \%$, the results suggest that principal hypothesis cannot be rejected. In this way, Johansen co-integrity test shows that there is no co-integration relationship between financial development and economic growth. According to this result, applicable specification is VAR model for identification of presence of causality among the related variables and the aspect of the causality.

As there is no co-integration between the sets, by taking the differences of variables causality relations have been analyzed VAR Granger causality model at the third stage. Relevant lag has been defined primarily with the help of VAR model. As can be seen from the results in Table 4, null hypothesis has been rejected, as probability value of chi-square test statistic which is estimated for unidirectional causality from LNPSC to LNCGDP is fewer than 5\% significance. According to this result, supply-leading hypothesis is valid for 1960-2013 periods in Turkey.

Table 4: Granger causality test results

\begin{tabular}{|l|c|c|}
\hline \multicolumn{1}{|c|}{ Null Hypothesis } & Chi Square & Prob. \\
\hline$\triangle$ LNPSC does not Granger cause $\triangle$ LNCGDP & 8.087047 & $0.0045^{*}$ \\
\hline$\triangle$ LNCGDP does not Granger cause $\triangle$ LNPSC & 1.810609 & 0.1784 \\
\hline
\end{tabular}

Note: * shows the causality at $5 \%$ significance level.

Source: Authors' calculations

We can conduct analysis with regard to identifying direction of the relationship between growth and financial development by using Toda-Yamamoto(where causality relationship is tested without needing foreknowledge on stability and cointegrity) test with a view to support the results derived from Granger Causality Test. As maximum integration level of the sets is one, lag lengths to be engaged in VAR model to be estimated ( $\mathrm{p}+\mathrm{dmax}$ ) shall be three. The results of Toda Yamamoto test which we use so as to identify the relationship between growth and financial development are summarized in the following Table 5.

Table 5: Toda-Yamamoto causality test results

\begin{tabular}{|l|c|c|}
\hline \multicolumn{1}{|c|}{ Null Hypothesis } & Chi Square & Prob. \\
\hline LNPSC does not Granger cause LNCGDP & 3.8151 & $0.0298^{*}$ \\
\hline LNCGDP does not Granger cause LNPSC & 0.0526 & 0.6645 \\
\hline
\end{tabular}

Note: ${ }^{*}$ shows the causality at $5 \%$ significance level.

Source: Authors' calculations 
Toda-Yamamoto test applied sets forth findings, supportive of supply-leading approach which suggests that causality relationship heads from financial development towards growth.

When the results obtained through Granger Causality Test and Toda-Yamamoto Approach are assessed, substantial overlap of two methods' results is observed. Having the same results from two different causality analysis methods strengthens the possibility of a unidirectional causality relationship between these two variables. Time-Varying Analysis has been conducted at final stage with an intention to check the validity of periodical causality of 1960-2013. Unidirectional causality relationship obtained through conventional Granger methods are derived by taking the whole sample period into consideration. Time-varying causality test results are shown in Figure 1 for testing stability of these results. In other words, not only formation of the causality but also alteration of this causality in time is analyzed in Figure 2. Causality periods of causality from LNPSC to LNCGDP are examined in Figure 2.

The values are reflected in Figure 2 for interpreting LR statistics which are calculated for Time-Varying Causality from LNPSC to LNCGDP. The values above " 0.2 " line in the figure shows that principal hypothesis which suggests absence of time-varying causality should be rejected.

Figure 2: Plot of rolling-sample results from LNPSC to GDP for Turkey.

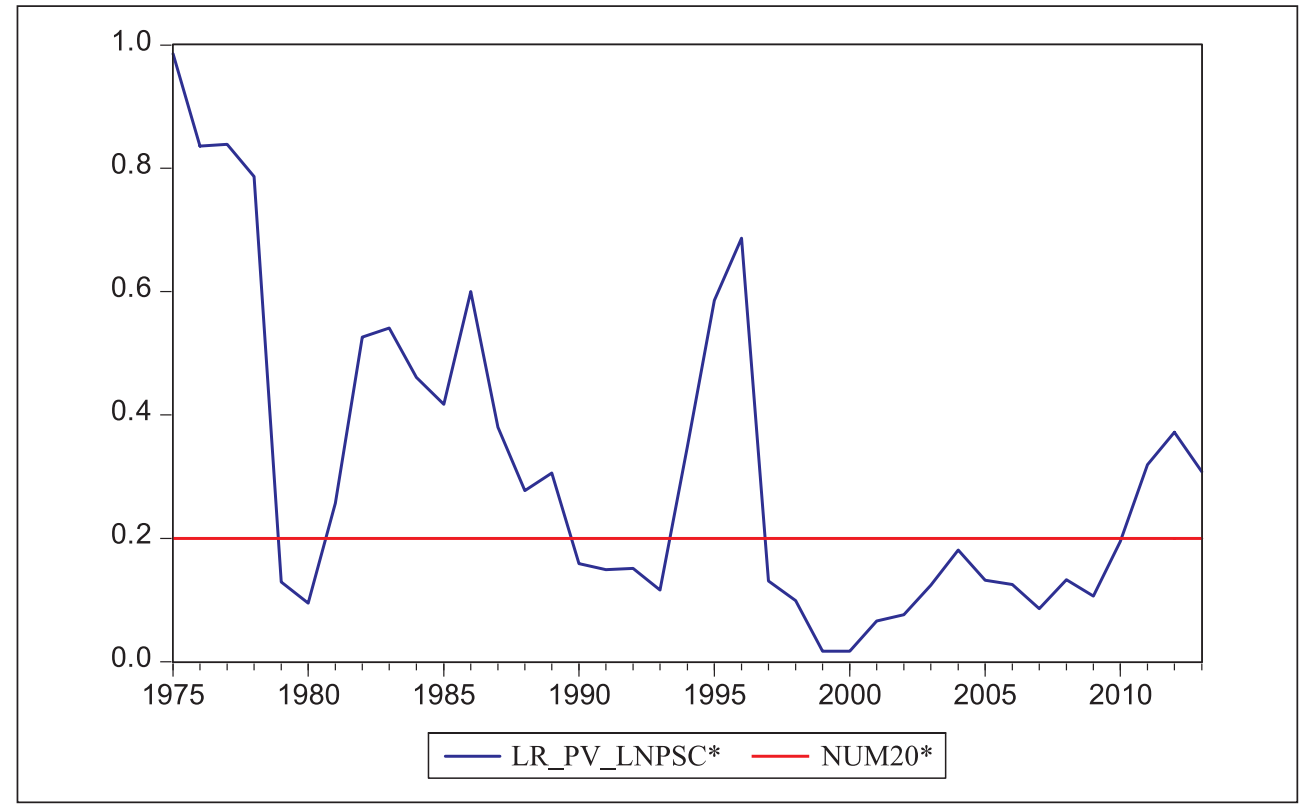

Notes: *LR_PV_LNPSC: LR statistics estimated for Time-Varying Causality from LNPSC to LNCGDP. ** Significance level at 0.20 .

Source: Authors' calculations 
According to the Figure 2 showing LR statistic values estimated for Time-Varying Causality, except for three periods, financial development at $20 \%$ significance level during sample period observed cannot be Granger cause of economic growth. These exceptional periods consist of 1981-1989, 1994-1996 and 20112013 chronologically. Throughout these periods, financial development at $20 \%$ significance level has predictive power on growth. ${ }^{6}$ Figure 1 indicates that causality relationship emerged between two variables along the periods when national and international financial fluctuations $(1993,1997,2008)$ and macro-economic policies and political transformation existed $(1979,1989,2001)$.

Figure 3 shows the bootstrap estimates of sum of the rolling coefficients measuring impact of LNPSC on LNCGDP. For Turkey, the results given in Figure 2 show that the null hypothesis that LNCGDP does not Granger-cause LNPSC is not rejected at the 5\% significance level during the full sample. The bootstrap rolling-sample results indicate that LNPSC had positive predictive power for LNCGDP mainly during the 1979, 1990-1993 and the1997-2010 sub periods.

Figure 3: Bootstrap estimate of the sum of the rolling coefficients for the impact of LNPSC on LNCGDP

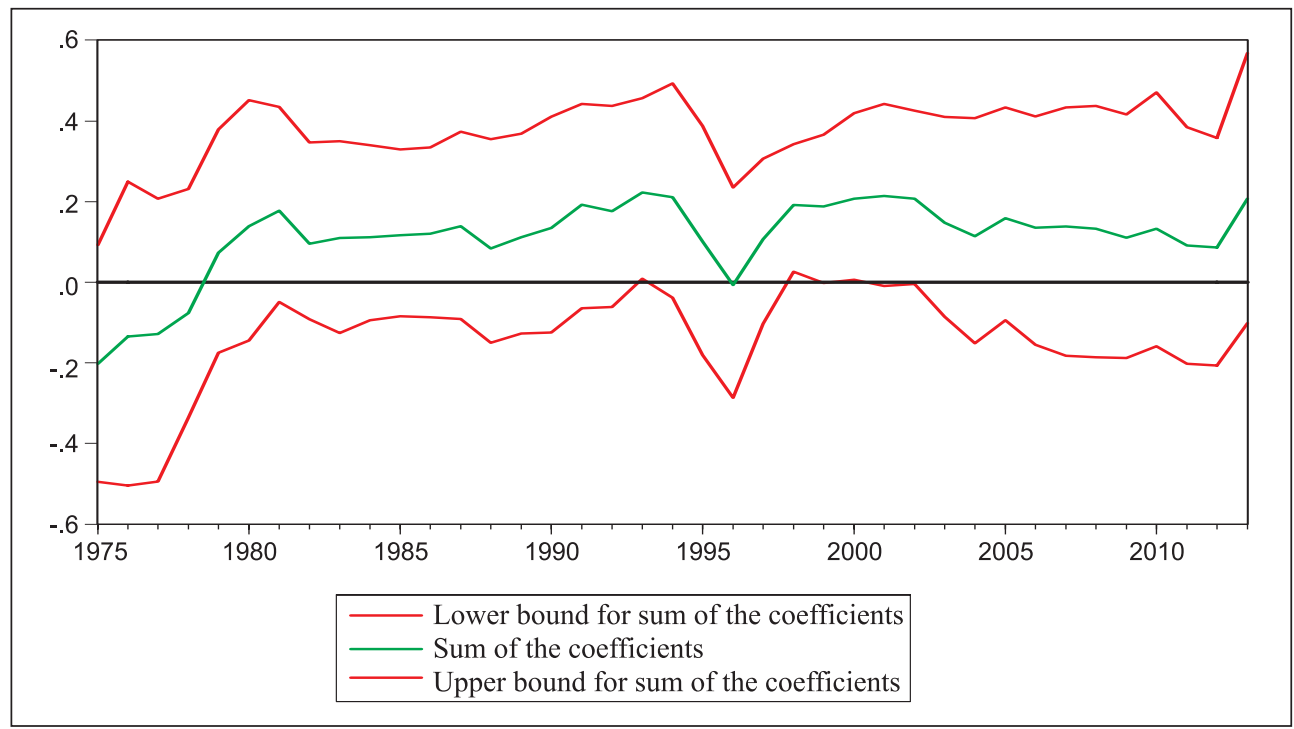

Source: Authors' calculations

$\overline{{ }^{6}}$ During these periods, the financial development has predictive power for growth at $20 \%$ significance level. 
The results of the rolling window Granger causality tests indicate three arguments below.

(a) The assumption of Granger Causality Test implying the causal relationship from the financial development to the economic growth is valid all over the sample period is not true.

(b) There exists a causal relationship in just three short terms (1979-80, 199093, 1997-2010).

(c) It is obvious that Granger Causality Tests don't come up with healthy results in the cases in which causal relationship changes over time, in other words, in the cases in which causal relationship is not stable.

\section{Empirical results and discussion}

Is there a relationship between economic growth and financial development in Turkey? If it is, is it stable over the time period of this study? This paper focuses on these two questions. The findings of the empirical research of the study approve 'the supply based hypothesis', in other words the empirical section indicates that the direction of the causal relationship is from the financial system to the economic growth. More precisely, it can be said that the structural characteristics of Turkey provide an appropriate background for the financial developments to stipulate economic growth. These findings should be regarded as the implication that the financial system provides the real sector with the funds for capital accumulation and technological improvement. Our findings imply that financial development plays a role in economic growth for the Turkey, in line with Gupta (1984), Jung (1986), Neusser and Kugler (1998), King ve Levine (1993), Fry (1995), Levine ve Zervos (1998) Demetrias and Hussein (1996), Choe and Moosa (1999), Rousseau and Watchell (2000), Shan vd. (2001), Beck et al. (2000), Levine et al. (2000), Christopoulos and Tsionas (2004), Dawson (2008).

On the other hand, according to the rolling window test this unilateral causal relationship from financial development to the economic growth isn't stable over time. From 1960 to 2013 three emerged a number of structural and reforms in Turkey. The transition from planned economy to free market and the transition from import substitution to free international trade and the transition from a suppressed financial market to a freer and more integrated financial market are some of these major changes. The empirical research of the study suggests that that causal relationship is valid for three sub-periods (1979, 1990-93 and 1997-2010).

The period from 1990 to 1993 coincides with financial liberalization. In 1989 capital movements were liberalized in Turkey. There are three main factors accounting for 
financial liberalization of Turkish economy: (a) the growth rate started to decline in the second half of 1980's and there emerged a motivation to take international capital in order to stimulate the economy. (b) It was aimed to carry out the requirements which international financial institutions demand to give credits. (c) Real sector investments were crowded out by increasing interest rates as the public sector that is to say local administrations and state-owned enterprises had taken huge domestic borrowings since 1986 . The emergency for real sector investments to increase played an important role in financial liberalization (Alper and Öniş, 2003). In line with these objectives there emerged an average growth rate of 5.2\% in 1990-1993.

The increase in capital inflows in 1990-1993 led to an increase in imports and private consumption and stimulated economic growth. In other words Turkish economy was based on domestic demand by encouraging private consumption and imports. Too high exchange rates and the customs union with EU promoted supply enabling cheap inputs. Under these circumstances Turkish economy had a structure in which growth is impossible without outsourcing (Rodrik, 2009). As a result of the increase in capital inflows the real sector had more borrowing opportunities. So the ratio of the funds transmitted to the real sector over total funds inclined. PSC (funds given to the real sector by banks / GDP) was 16.5\% in 1990 and became $18.5 \%$ in 1993 by a stable increase. However this process was ceased as a result of the crisis in the money, capital and exchange markets in Turkey in 1994.

The period from 1997 to 2010 (if the crisis years of 2000 and 2001 excluded) coincided with banking reform. The banking sector was reorganized properly at the end of 1990's. Turkish banking reform was carried out in cooperation with International Money Fund (IMF) in order to create a banking sector which is capable of competing in international markets (Gültekin-Karakaş, 2009).

The reform was processed in three channels, which were a new banking law which requires international norms, a quality governance and the independence of the Central Bank (Bakır, 2009). The most interesting character of the standby (with IMF) in 1999 was the emphasis on the institutional reforms based on the supervisory government concept. There were carried out some permanent institutional changes such as supervision of banks by The Banking Regulatory and Supervisory Agency, which had an autonomous structure and the independence of the Central Bank. And that European Council declared Turkey as a candidate country in Helsinki submit accelerated the reform process.

'Transition to the Strong Economy Program', which was promulgated after 2000 and 2001 crises dominated the major changes which were explained above. And of course one of the main characteristics of this program was to reorganize the banking sector. Inside this program 'Restructuring Banking Sector Program' had legislative and institutional regulations. As mentioned before the independence of the Central Bank, efficient supervision of banking and stocks and bonds sectors, new competition 
regulations and fortification of the autonomous institutions in critical sectors led a more comprehensive supervision mechanism relative to the countries with similar development levels. This well-designed structure accounts for a worldwide exemplary performance of Turkish economy with positive economic growth rate for 27 successive quarters from 2003 to 2008 and minimization of the potential costs of 2008-2009 global crises. (Unay, 2009) After the start of negotiations with EU on full membership the investment atmosphere changed dramatically. In European investors' vision Turkey became an appropriate place for long term investment. It can be said that the effects of the reforms in financial sector and the effects of negotiations supported each other as one effect made the other bigger. Since the great transition of Turkey after 2002, the concepts of supervisory government (which takes into account the potential factors of financial and macroeconomic crises) and policy autonomy has established. That the banks were abided by the economic criteria while giving credits after the reform and long term international capitals increased led to a dramatic increase in the quantity and productivity in credits given to the real sector. Concordantly in 2013 PSC became 70\%.

Interestingly, we detect causality for the Turkey, after or during periods of recessions (1979, 2000-2001), i.e., when the Turkish economy was in a weak state or was recovering. The capital accumulation process of Turkey faced two significant crises which took place at the end of 1970's and in 2001. And these two crises stimulated two great transitions in capital accumulation process. But it seemed ambiguous why there exists a causal relationship from financial development to economic growth in crisis years.

\section{Conclusion}

The main contribution of this paper is that there is a causal relationship of financial development and economic growth however this relationship changes over time periods. Therefore the hypothesis of this study is approved. This paper contributes to the growing literature on the finance-economic growth relationship using the bootstrap rolling window approach as it focuses the stability of variables over time. The results of the study emphasize the potential risk of misleading conclusions based on the standard Granger causality tests which neither accounts for structural breaks nor time variation in the relationship between financial deepening and economic growth. The findings of the study reveal that economic policy change, economic crises and political instability in Turkey and the period studied are predictive factors on unidirectional relationship from financial development to growth. Econometric analyses indicate that the direction of the causal relationship between growth and financial development is sensitive to the demonstrator of financial development employed in these papers. However, what is lacking in this study is that causality between variables was not separated as positive and negative 
shocks and the natural limit of the demonstrator of the study for financial deepness due to the two factors (i) having used only one demonstrator based on banking for financial development and (ii) the probability of this demonstrator not to reflect all sides of multidimensional concept of financial development could be the limits of this study. In the light of this study, further studies, analyses and investigations should take into account the nature (non-linear, asymmetric, and time-varying) of the relationship between financial development and growth. The model used in the study should be expanded. Especially a sophisticated financial development index which allows the concept to be analyzed in most detail and an approach which reflects the structural properties of any economy should be tried to develop for such studies. Starting from this point of view, we can put forward three policy suggestions for financial development to support economic growth in the medium term or in the long-run. First of all, financial development is crucial for economic growth. However the structural reforms based only on making financial sector bigger and deeper should be insufficient to accelerate economic growth. Rather, growth-friendly financial reforms enabling the financial sector to do its transmitting function. Second, the fact that the relationship from financial development to economic growth isn't stable indicates that financial development is vital for growth but besides this economic and political stability accounts for growth as well. As policy makers design policies for economic growth, they should pay attention to the political stability and financial development rank of the country. To sum up, financial development is required for growth in Turkey but it isn't a sufficient condition for a stable growth. And finally time matters. It should be said that for policy makers that economic structure has a number of dimensions and it is not useful to implicate a policy without considering the most important variable: time. Each policy implications should consider that their original assumptions might change over time as the all relationships change simultaneously.

\section{References}

Al-Yousif, Y.K. (2002) "Financial Development and Economic Growth: Another Look at the Evidence from Developing Countries", Review of Financial Economics, Vol. 11, No. 2, pp. 131-150, doi: 10.1016/s1058-3300(02)00039-3.

Acaravc1, A., Ozturk, I., Acaravc1, S.K. (2007) "Finance-Growth Nexus: Evidence from Turkey", International Research Journal of Finance and Economics, Vol. 11, No. 1, pp. 30-40, doi: 10.2139/ssrn.1401590.

Acaravci, S. K., Ozturk, I., Acaravci, A. (2009) "Financial Development and Economic Growth: Literature Survey and Empirical Evidence from SubSaharan African Countries: Economics", South African Journal of Economic and Management Sciences, Vol. 12, No. 1, pp. 11-27. 
Alper, C. E., Onis., Z. (2003) "Financial Globalisation, The Democratic Deficit and Recurrent Crises in Emerging Markets: The Turkish Experience in the Aftermath of Capital Account Liberalisation", Emerging Markets Finance and Trade, Vol. 39, No. 3, pp. 5-26, doi: 10.1080/1540496X.2003.11052542.

Ang, J. B., McKibbin, W. J. (2007) "Financial Liberalization, Financial Sector Development and Growth: Evidence from Malaysia", Journal of Development Economics, Vol. 84, No. 1, pp. 215-233, doi: 10.1016/j.jdeveco.2006.11.006.

Araç, A., Ozcan, S. K. (2014) "The Causality between Financial Development and Economic Growth: The Case of Turkey", Journal of Economic Cooperation and Development, Vol. 35, No. 3, pp. 171-198.

Arestis, P., Demetriades, P. (1997) "Financial Development and Economic Growth: Assessing the Evidence", The Economic Journal, Vol. 107, No. 442, pp. 783-799, doi: 10.1111/1468-0297.00193.

Arestis, P., Demetriades, P. O., Luintel, K. B. (2001) "Financial Development and Economic Growth: The Role of Stock Markets", Journal of Money, Credit And Banking Vol. 33, No. 1, pp. 16-41, doi: 10.2307/2673870.

Arslanturk, Y., Balcilar, M., Ozdemir, Z. A. (2011) "Time-Varying Linkages Between Tourism Receipts and Economic Growth in a Small Open Economy”, Economic Modelling, Vol. 28, No. 1, pp. 664-671, doi: 10.1016/j.econmod.2010.06.003.

Bakir, C. (2009) "Wobbling but Still on its Feet: The Turkish Economy in the Global Financial Crisis", South European Society and Politics, Vol. 14, No. 1, pp. 71-85, doi: 10.1080/13608740902995869.

Balcilar, M., Ozdemir, Z. A., Arslanturk, Y. (2010) "Economic Growth and Energy Consumption Causal Nexus Viewed Through a Bootstrap Rolling Window”, Energy Economics, Vol. 32, No. 6, pp. 1398-1410, doi: 10.1016/j. eneco.2010.05.015.

Bangake, C., Eggoh, J. C. (2011) "Further Evidence on Finance-Growth Causality: A Panel Data Analysis", Economic Systems, Vol. 35, No. 2, pp. 176-188, doi: 10.1016/j.ecosys.2010.07.001.

Baltagi, B.H., Demetriades, P.O. Law, S.H. (2009) "Financial Development and Openness: Evidence from Panel Data, Journal of Development Economics, Vol. 89, No. 2, pp. 285-296, doi: 10.2139/ssrn.1808903.

Beck, T., Levine, R. Loayza, N. (2000) "Finance and The Sources of Growth", Journal of Financial Economics, Vol. 58, No. 1-2, pp. 261-300, doi: 10.1016/ s0304-405x(00)00072-6.

Calderón, C., Liu, L. (2003) "The Direction of Causality Between Financial Development and Economic Growth", Journal of Development Economics, Vol.72, No.1, pp. 321-334, doi: 10.1016/s0304-3878(03)00079-8.

Choe, C., Moosa, I. A. (1999) "Financial System and Economic Growth: The Korean Experience”, World Development, Vol. 27, No. 6, pp. 1069-1082, doi: 10.1016/s0305-750x(99)00042-x. 
Christopoulos, D. K., Tsionas, E. G. (2004) "Financial Development and Economic Growth: Evidence from Panel Unit Root and Cointegration Tests", Journal of Development Economics, Vol. 73, No. 1, pp. 55-74, doi: 10.1016/j. jdeveco.2003.03.002.

Çetintaş, H., Barışık, S. (2003) "Banks, Stock Market and Economic Growth: Cointegration and Causality Analysis Case of Turkey (1989-2000)", ISE Review, Vol. 7, No. 25-26, pp. 1-17.

Dawson, P. J. (2008) "Financial Development and Economic Growth in Developing Countries", Progress in Development Studies, Vol. 8, No. 4, pp. 325-331, doi: 10.1177/146499340800800402.

Demetriades, P., Hussein, K. (1996) "Does Financial Development and Economic Growth? Time Series Evidence From 16 Countries", Journal of Development Economics, Vol. 51, No. 2, pp. 387-411, doi: 10.1016/s0304-3878(96)00421-x.

Demetriades, P., Luintel, K. (1996) "Financial Development, Economic Growth and Banking Sector Controls: Evidence from India", The Economic Journal, Vol. 106, No. 435, pp. 359-374, doi: 10.2307/2235252.

Demirhan, E., Aydemir, O., Inkaya, A. (2011) "The Direction of Causality Between Financial Development and Economic Growth: Evidence from Turkey", International Journal of Management, Vol. 28, No. 1, pp. 3-19.

Engle, R., Granger, C. W. J. (1987) "Cointegration and Error Correction: Representation, Estimation and Testing", Econometrica, Vol. 55, No. 1, pp. 251276, doi: 10.2307/1913236.

Fry, M. J. (1995) Interest and Banking in Economic Development, Baltimore: John Hopkins University Press.

Gupta, K. L. (1984) Finance and Economic Growth in Developing Countries, London: Croom Helm.

Hassan, M. K., Sanchez, B., Yu, J. S. (2011) "Financial Development and Economic Growth: New Evidence from Panel Data" The Quarterly Review of Economics and Finance, Vol. 51, No. 1, pp. 88-104, doi: 10.1016/j.qref.2010.09.001.

Herwartz, H., Walle, Y.M. (2014) "Determinants of the Link Between Financial and Economic Development: Evidence from a Functional Coefficient Model”, Economic Modelling, Vol. 37, No. 1, pp. 417-427, doi: 10.1016/j. econmod.2013.11.029.

Hsiao, C. (2003) Analysis of Panel Data, Cambridge: Cambridge University Press.

Hsueh, S. J., Hu, Y. H., Tu, C. H. (2013) "Economic Growth and Financial Development in Asian Countries: A Bootstrap Panel Granger Causality Analysis", Economic Modelling, Vol. 32, No. 1, pp. 294-301, doi: 10.1016/j. econmod.2013.02.027.

Ismihan, M., Ozkan, F. G. (2012) "Public Debt and Financial Development: A Theoretical Exploration", Economics Letters, Vol. 115, No. 3, pp. 348-351, doi: 10.1016/j.econlet.2011.12.040. 
Ismihan, M., Dinçergök, B., Cilasun, S. M. (2013) "Finance, Instability, Debt and Growth: The Turkish Case, 1980-2010" In EY International Congress on Economics I (EYC2013), October 24-25, 2013, Ankara, Turkey (No. 271). Ekonomik Yaklasim Association.

Ismihan, M., Dinçergök, B. Cilasun, S. M. (2016) "Revisiting the finance-growth nexus: the Turkish case, 1980-2010", pp. 1-14, Applied Economics, doi: 10.1080/00036846.2016.1226487.

Johansen, S. (1988) "Statistical Analysis of Cointegration Vectors" Journal of Economic Dynamics and Control, Vol. 12, No. 2, pp. 231-254, doi: 10.1016/0165-1889(88)90041-3.

Johansen, S. (1991) "Estimation and Hypothesis Testing of Cointegration Vectors in Gaussian Vector Autoregressive Models" Econometrica: Journal of the Econometric Society, pp. 1551-1580, doi: 10.2307/2938278.

Johansen, S., Juselius, K. (1990) "Maximum Likelihood Estimation and İnference on Cointegration with Applications To The Demand For Money" Oxford Bulletin of Economics and Statistics, Vol. 52, No. 2, pp. 169-210, doi: /10.1111/ j.1468-0084.1990.mp52002003.x.

Jung, W. S. (1986) "Financial Development and Economic Growth: International Evidence", Economic Development and Cultural Change, Vol. 34, No. 2, pp. 333-346, doi: 10.1086/451531.

Kar, M., Peker, O., Kaplan, M. (2008) "Trade liberalization, financial development and economic growth in the long term: The case of Turkey", South East European Journal of Economics and Business, Vol. 3, No. 2, pp. 25-38, doi: 10.2478/v10033-008-0012-x.

Kar, M., Nazlığlu, Ş., Ağır, H. (2011) "Financial Development and Economic Growth Nexus in the MENA Countries: Bootstrap Panel Granger Causality Analysis", Economic Modelling, Vol. 28, No. 1, pp. 685-693, doi: 10.1016/j. econmod.2010.05.015.

Gültekin-Karakaş, Derya (2009) "Sermaye'nin Uluslararasılaşması Sürecinde Türkiye Banka Reformu ve Finans Kapital-içi Yeniden Yapılanma", Praksis, No. 19, pp. 95-131.

King, R. G., Levine, R. (1993) "Finance and Growth: Schumpeter might be 'Right", Economic Journal, Vol. 107, No. 1, pp. 771-782, doi: 10.2307/2118406.

Levine, R., Zervos, S. (1998) "Stock Markets, Banks, and Economic Growth" American Economic Review, Vol. 88, No. 1, pp. 537-558.

Levine, R. (1998) "The Legal Environment, Banks, and Long-run Economic Growth", Journal of Money, Credit and Banking, Vol. 30, No. 1, pp. 596-613, doi: $10.2307 / 2601259$.

Levine, R., Loayza, N., Beck, T. (2000) "Financial Intermediation and Growth: Causality and Causes", Journal of Monetary Economics, Vol. 46, No. 1, pp. 31-77, doi: 10.1016/s0304-3932(00)00017-9. 
Luintel, K.B., Khan, M. (1999) “A Quantitative Reassessment of the FinanceGrowth Nexus: Evidence from a Multivariate VAR", Journal of Development Economics, Vol. 60, No. 2, pp. 381-405, doi: 10.1016/s0304-3878(99)00045-0.

Nazlioglu, S., Menyah, K., Wolde-Rufael, Y. (2014) "Financial Development, Trade Openness and Economic Growth in African Countries: New Insights from a Panel Causality Approach", Economic Modelling, Vol. 37, No. 1, pp. 386-394, doi: 10.1016/j.econmod.2013.11.044.

Nazlioglu, S., Ege, I., Bayrakdaroglu, A. (2009) "Financial Development and Economic Growth: Cointegration and Causality for Turkey", Banking and Finance Letters, Vol. 1, No. 2, pp. 59-66.

Neusser, K., Kugler, M. (1998) "Manufacturing Growth and Financial Development: Evidence from OECD Countries", Review of Economics and Statistics, Vol. 80, No. 4, pp. 638-646, doi: 10.1162/003465398557726.

Nyakabawo, W., Miller, M. S., Balcilar M., Das, S., Gupta, R. (2015) “Temporal causality between house prices and output in the US: A bootstrap rollingwindow approach", The North American Journal of Economics and Finance, vol. 33, pp. 55-73, doi: 10.1016/j.najef.2015.03.001.

Odhiambo, Nicholas M. (2008) "Financial Depth, Savings and Economic Growth in Kenya: A Dynamic Causal Linkage", Economic Modelling, Vol. 25, No. 4, pp. 704-713, doi: 10.1016/j.econmod.2007.10.009.

Ozturk, I. (2008), "Financial Development and Economic Growth: Evidence from Turkey", Applied Econometrics and International Development, Vol. 8, No. 1, pp. 85-98.

Pradhan, R. P., Dasgupta, P., Bele, S. (2013), "Finance, Development and Economic Growth in BRICS: A Panel Data Analysis", Journal of Quantitative Economics, Vol. 11, No. 1-2, pp. 308-322.

Rodrik, D. (2009), "The Turkish Economy after the Crisis", Ankara: TEA (Turkish Economic Association Discussion Paper No. 2009/9).

Rousseau, P. L., Wachtel, P. (2000) "Equity Markets and Growth: Cross-Country Evidence on Timing and Outcomes, 1980-1995", Journal of Banking and Finance, Vol. 24, No. 12, pp. 1933-1957, doi: 10.1016/s0378-4266(99)00123-5.

Schumpeter, J.A. (1911), The Theory of Economic Development, Cambridge: Harvard University Press.

Shan, J. Z., Morris, A. G., Sun, F. (2001) "Financial Development and Economic Growth: An Egg-and-Chicken Problem?", Review of International Economics, Vol. 9, No. 3, pp. 443-454, doi: 10.1111/1467-9396.00291.

Shan, J. Z., Morris, A. (2002) "Does Financial Development 'Lead' Economic Growth?", International Review of Applied Economics, Vol. 16, No. 2, pp. 153-168, doi: 10.1080/02692170110118885. 
Soytaş, U., Küçükkaya, E. (2011) "Economic Growth and Financial Development in Turkey: New Evidence", Applied Economics Letters, Vol. 18, No. 6, pp. 595-600, doi: 10.1080/13504851003761764.

Toda, H. Y., Yamamoto, T. (1995) "Statistical Inference in Vector Autoregressions with Possibly Integrated Processes", Journal of Econometrics, Vol. 66, No. 1, pp. 225-250, doi: 10.1016/0304-4076(94)01616-8.

The Central Bank of the Turkish Republic (2002) The Causality Between Financial Development and Economic Growth: The Case of Turkey, Ankara: TCMB (Research Department Working Paper, 3).

Unay, Sadık (2013) Kalkınmacı Modernlik: Küresel Ekonomi Politik ve Türkiye, İstanbul:Küre Yayınları.

Yang, Y. Y., Yi, M. H. (2008) "Does Financial Development Cause Economic Growth? Implication for Policy in Korea", Journal of Policy Modeling, Vol. 30, No. 5, pp. 827-840, doi: 10.1016/j.jpolmod.2007.09.006.

Yılmaz, E., Kayalıca, O (2002) "Finance and Growth in Turkey: Causality", ISE Review, Vol. 6, No. 24, pp. 33-49.

Zivot, E., Andrews, D.W., (2012) "Further evidence on the great crash, the oil-price shock, and the unit-root hypothesis" Journal of Business \& Economic Statistics, Vol. 10, No. 3, pp. 251-270, doi: 10.1080/07350015.1992.10509904. 


\title{
Utjecaj financijskog razvoja na rast: analiza vremenske kauzalnosti
} za Tursku

\author{
Mehmet Zeki Ak ${ }^{1}$, Mustafa Kirca ${ }^{2}$, Nurullah Altintaş ${ }^{3}$
}

\begin{abstract}
Sažetak
Cilj ovog istraživanja je utvrditi je li uzročna veza između financijskog razvoja $i$ ekonomskog rasta u Turskoj stabilna tijekom vremena. U tu svrhu istražuje se uzročno-posljedična veza između financijskog razvoja i ekonomskog rasta u Turskoj putem godišnjih podataka za razdoblje od 1960.-2013. Za razliku od prethodnih studija u literaturi, uzimajući u obzir da se uzročno-posljedična veza između financijskog razvoja i ekonomskog rasta može mijenjati ovisno o vremenu, primjenjuje se test vremenske kauzalnosti kojeg su prethodno razvili Balcilar, Özdemir i Arslanturk (2010). Rezultati pokazuju da postoji jednosmjerna uzročnoposljedična veza između financijskog razvoja i gospodarskog rasta i taj se odnos mijenja ovisno o vremenu. Vidljivo je da je jednosmjerna uzročnost iz financijskog razvoja na gospodarski rast nastala tijekom razdoblja financijske krize i političke krize. Osnovni je zaključak da ne postoji stabilna uzročna veza između financijskog razvoja i ekonomskog rasta u Turskoj u danom vremenskom razdoblju.
\end{abstract}

Ključne riječi: financijski razvoj, rast, vremenska kauzalnost

JEL klasifikacija: C2, G10, G20, O43

1 Docent, Department of Economics, Faculty of Political Sciences, Sakarya University, 54187 Serdivan, Sakarya, Turska. Znanstveni interes: financijski razvoj, gospodarski rast. Tel.: +90 264295 6195.E-mail:mak@sakarya.edu.tr.

2 Znanstveni novak, Institute of Social Sciences, Anadolu University, 26470 Eskişehir, Turska. Znanstveni interes: makroekonomija, ekonomika turizma, analiza vremenskog niza /serije. Tel.: +90222 335 0580-1269. E-mail: mustafakirca@anadolu.edu.tr.

3 Znanstveni novak, Department of Economics, Faculty of Political Sciences, Sakarya University, 54187 Serdivan, Sakarya, Turska. Znanstveni interes: financijski razvoj, gospodarski rast, ekonometrija.Tel.: +90264295 6195.E-mail:naltintas@sakarya.edu.tr (autor za korespodenciju). 